\title{
In vitro fertilization in cattle: a review
}

\author{
T Greve *, V Madison
}

Royal Veterinary and Agricultural University, Department of Reproduction

and Animal Biotechnology Research Centre, 3 Bülowsvej, DK-1870 Frederiksberg C, Denmark

\author{
(4th Franco-Czechoslovak Meeting, Prague 1990)
}

\begin{abstract}
Summary - In vitro maturation and fertilization of cattle oocytes and subsequent in vitro culture of zygotes and embryos is discussed in the context of recent encouraging data. Mass production of embryos produced in this way in the future will have a great impact on animal production and animal breeding plans, for example the so-called MO-ET (multiple ovulation and embryo transfer) plan which aims at establishing nucleus breeding herds.
\end{abstract}

In vitro / cattle / oocytes / sperm / embryo

Résumé - Fécondation in vitro chez les bovins (revue). Les résultats récents et encourageants sur la maturation et la fécondation in vitrod'ovocytes de vache et la culture in vitro subséquente des zygotes sont analysés. La production en masse d'embryons aura un grand impact sur la production et la planification de l'élevage, par exemple le plan OM-TE (ovulation multiple et transfert d'embyons).

bovin / maturation ovocytalre / sperme / fécondation in vitro / embryon

\section{INTRODUCTION}

The natural in vivo process of fertilization and early embryonic development involves innumerable factors, both wellstudied and unexplored, which interact to affect each event of the process. Therefore, it is not surprising that results obtained using the techniques of in vitro maturation (IVM), in vitro fertilization (IVF) and in vitro culture (IVC) are neither optimum nor predictable. Several groups have reported the occurrence of pregnancies and the birth of calves following IVM and IVF
(Critser et al, 1986; Lu et al, 1987, 1989; Xu et al, 1987; Goto et al, 1988; Sirard et al, 1988; Stubbings et al, 1988; Utsumi et al, 1988; Greve et al, 1989a; Pavlok et al, 1989; Pollard et al, 1989; Gordon and Lu, 1990), but the total number of offspring on a worldwide basis is still limited (Polge, personal communication, 1988). All data clearly reflect the difficulty of applying in vitro techniques toward research and reproduction, and indicate that a much better understanding of the many processes involved in reproduction must be gained before the in vitro system can successfully be used at an optimal level.

\footnotetext{
- Correspondence and reprints
} 
Highlighted here are some practical aspects of IVM, IVF and IVC. For a more extensive review of the state of the art of in vitro maturation and/or fertilization, see Thibault et al (1976, 1987), Wright $\mathrm{Jr}$ and Bondioli (1981), Moor et al (1983), Brackett (1983, 1985), Ball et al (1984), First and Parrish (1987), Le Guienne et al (1988), Staigmiller (1988), LeibfriedRutledge et al (1989) and Gordon and Lu (1990).

\section{IN VITRO MATURATION}

\section{Cumulus oocyte complexes}

The morphological events associated with in vitro oocyte maturation very closely resemble those occurring in vivo (Hyttel et $a l, 1989 \mathrm{c})$, except that the process in vitro proceeds more quickly than in vivo (King et al, 1986). From the onset it must be emphasized that in vitro maturation, by and large, yields oocytes with a lowered potential for developmental capacity in comparison to in vivo matured oocytes (LeibfriedRutledge et al, 1986a, 1987; Pavlok et al, 1988).

The criteria for evaluation and assessment of the quality of follicular and even oviductal oocytes are not well established. In addition, conditions for maturation in vitro vary between research groups and have not been standardized. Multiple integrated factors play important roles in the completion of meiotic and cytoplasmic maturation in vitro, and the capacity of such an oocyte upon fertilization to develop into a viable blastocyst.

The size of the follicle from which the oocyte originates does not seem to influence its ability to undergo nuclear maturation (Leibfried and First, 1979; Fukui and Sakuma, 1980; Grimes and Ireland, 1986) or even to be fertilized in vitro (LeibfriedRutledge et al, 1985). Recent evidence suggests, however, that oocytes which have not completed their growth, and therefore have not synthesized adequate amounts of RNA, possess a reduced capacity for early embryonic development (Crozet et al, 1986; Crozet, 1989). Since the effect of follicle and oocyte size on IVF and IVM has still not been sufficiently studied and understood, one should, as emphasized by Staigmiller (1988), attempt to use medium-sized follicles as the origin of oocytes to be used for maturation in vitro. This concept has recently been substantiated by Tan and Lu (1990).

The macroscopic appearance of the follicle may also be used to select oocytes capable of maturation and development. Oocytes originating from translucent follicles (Grimes and Ireland, 1986) have reduced potential because of advanced atresia.

Assessment of characteristics of the cumulus oocyte complexes acquired by aspiration of follicles has been used by many research groups to estimate oocyte quality. Oocytes surrounded by a tight, complete, multilayered cumulus investment and with an ooplasm void of rough granules seem to be most capable of undergoing normal maturation and fertilization in vitro (Leibfried and First, 1979; Fukui and Sakuma, 1980; Greve et al, 1984; Hensleigh and Hunter, 1985; Xu et al, 1987; Shioya et al, 1988; Greve et al, 1989b; Sirard, 1989; Younis et al, 1989; Kruip et al, 1990; Gordon and Lu, 1990; Yang and Lu, 1990).

The optimal time and temperature for ovary transport from the abattoir and until initiation of culture has been examined by Yang et al (1990). These authors found that ovaries can be stored for up to $8 \mathrm{~h}$ at $25^{\circ} \mathrm{C}$ without a reduction in the rate of fertilization or in the capacity of early embryos to develop to blastocysts in vitro. 
Storage for over $4 \mathrm{~h}$ at $37^{\circ} \mathrm{C}$ or at $4^{\circ} \mathrm{C}$ reduced the viability. It is known that periods of reduced temperature during maturation result in chromosomal abnormalities in sheep oocytes (Moor and Crosby, 1985). Katska and Smorag (1985) suggested that incubation temperatures of $35-37^{\circ} \mathrm{C}$ assure a higher viability of bovine oocytes as judged by fluorescent staining. However, the results of Ball et al (1982) and Lenz et al (1983a) clearly indicate that the penetration rate of cattle oocytes in vitro is significantly correlated with the temperature during IVM; penetration rates of $36 \%$ and $58 \%$ result following IVM at $37^{\circ} \mathrm{C}$ and $39^{\circ} \mathrm{C}$, respectively. Presently, virtually all groups are performing IVM/IVF at $39^{\circ} \mathrm{C}$. The time period of incubation required to complete meiotic maturation ranges from 18-27 $h$ (King et al, 1986; Xu et al, 1986a; Süss et al, 1988) and is somewhat dependent on the thickness of the cumulus mass ( $\mathrm{Xu}$ et al, 1986a).

It has been demonstrated that culture of follicle-enclosed oocytes leads to a higher rate of maturation and fertilization than culture of aspirated oocytes (Fukui et al, 1987; Staigmiller, 1988). However, most research groups use oocytes either aspirated directly from ovarian follicles or released from the follicles after dissection.

\section{Media, supplementation and culture conditions}

A variety of media have been used for IVM. Bavister (1989) emphasized the importance of proper media preparation and the use of the hamster sperm bioassay to test water, media, filters, etc for toxicity. For review articles concerning quality control in the laboratory, see Boone and Shapiro (1990) and Schiewe et al (1990).

Although Ham's F-10, Ham's F-12, Brinsters BMOC-3, KRB and MEM have been used successfully in many studies (Staigmiller, 1988; Leibfried-Rutledge et al, 1989), both TCM 199 and TALP (Parrish et al, 1986; Sirard et al, 1988) seem to emerge as the media of choice for IVM/IVF work. In our laboratory we initially used Ham's F-10, but have recently changed to TCM 199, which we found to give a nuclear maturation rate of $80 \%$. The $\mathrm{pH}$ and osmolarity should be 7.2 to 7.4 and $285-300$ mOsm, respectively, and in most cases the oocytes were cultured in $5 \% \mathrm{CO}_{2}$ in air.

In vivo, the LH surge triggers final maturation and ovulation of the selected oocytes. A delicate and well balanced hormonal microenvironment ensures that the signaling between the oocyte and its surrounding is kept within certain well defined limits (Callesen et al, 1986). It seems to be of paramount importance that the hormonal environment (particularly the steroids) is well-balanced during the maturation process (Baker and Hunter, 1978; Moor, 1978; Moor et al, 1980; Osborn and Moor, 1983; Moor and Seamark, 1986). In order to achieve this goal a variety of hormones, such as $\mathrm{FSH}, \mathrm{LH}$, estradiol-17 $\beta$ and even progesterone, were added to the medium. It is generally believed that the addition of hormones provides oocytes with higher viabiblility, ie oocytes which undergo normal fertilization and embryonic development at a higher rate (Fukui et al, 1982a, b; Fukushima and Fukui, 1985; Fukui, 1989; Younis et al, 1989). However it must be realized that the initial hormonal environment of the maturation medium changes during incubation if the oocytes are cultured in medium under oil ( $\mathrm{Xu}$ et al, 1988a). In a recent study no beneficial effect of the addition of hormones was observed with regard to subsequent embryo development (Sirard et al, 1988). In our laboratory and many others, addition of hormones has been substituted by estrous cow serum (ECS), which has proven to be very efficient for attaining oocytes with high 
developmental competence (Lu et al, 1987, 1988; Xu et al, 1987; Fukui and Ono, 1988, 1989; Lu et al, 1989; Fukui et al, 1989). This may be due to the presence of hormones in ECS that may support the oocyte maturation.

Oocyte maturation in vivo is arrested by follicular substances that are not welldefined. Follicle-enclosed oocytes remain arrested in the dictyate stage of meiosis until the endogenous or exogenous exposure to gonadotropins causes the resumption of meiosis. By contrast, oocytes removed from their follicles spontaneously resume meiosis. For in vitro purposes, attempts have been made to arrest or at least delay maturation of bovine aspirated oocytes. Liehman et al (1986) showed that addition of dbc-AMP did not prevent oocyte maturation, but had a beneficial effect on the sperm penetration rate. Sirard and First (1988) showed that dbc-AMP, IBMX and hypoxantine transiently (up to $21 \mathrm{~h}$ ) prevent resumption of meiosis; an effect that was also observed when the oocytes were cultured with bovine follicular fluid (BFF) and NaF + BFF (Sirard, 1990). This last observation has resulted in addition of BFF to maturation medium, but so far neither of the above substances have been added to media on a routine basis.

The somatic cells surrounding an oocyte facilitate production of nutrients and their transport into an oocyte. In addition they generate signals which control and regulate oocyte metabolism, as well as nuclear and cytoplasmic maturation (Osborn and Moor, 1982; Moor and Seamark, 1986). Supplementation of maturation media with additional granulosa cells has been performed in a number of studies and has been found to be absolutely essential for achieving full developmental competence (Staigmiller and Moor, 1984; Critser et al, 1986; Lu et al, 1987; Lutterbach et al, 1987; Fukui and Ono, 1988; Fukui et al, 1988; Leibfried-Rutledge et al,
1989). In our system cumulus oocyte complexes were cultured without supplementary granulosa cells (Madison et al, 1991).

Addition of serum to maturation medium is one of the requirements for achievement of cumulus expansion and complete oocyte maturation, and attainment of normal embryonic development in cattle. Fetal calt serum (FCS) has been shown to be superior to bovine serum albumin (BSA) (Leibfried-Rutledge et al, 1986b). As mentioned earlier, ECS is now the serum of choice and seems to increase cleavage rate in comparison to FCS (Fukui, 1989), probably because of the content of hormones. Serum collected around the time of onset of estrus improves in vitro development after IVF (Sanbuissho and Threlfall, 1989; Younis et al, 1989).

The size of the droplets in which the oocytes are cultured and the number of oocytes per droplet varies from lab to lab. In our laboratory 10 oocytes were cultured in $100-\mu$ droplets under paraffin oil.

\section{IN VITRO FERTILIZATION}

\section{Semen and semen treatment}

For practical purposes ejaculated semen is used for bovine IVF and seems to give rise to more normal eggs than epididymal spermatozoa (Pavlok et al, 1988).

The first calf born following in vitro fertilization of cattle oocytes matured in vivo was the result of using fresh semen treated with high ionic strength solution (HIS) (Brackett et al, 1982). Since then, this technique has also been used successfully by other groups (Greve et al, 1984; Sirard and Lambert, 1985, 1986), and also for frozen/thawed semen (Bondioli and Wright, 1983). 
Later, Fukui et al (1983) performed studies which revealed that semen treatment with bovine follicular fluid (BFF) resulted in a higher fertilization rate than treatment with HIS, probably due to a proteoglycan in the BFF known to enhance the acrosome reaction (Lenz et al, 1982).

Subsequent detailed studies have clearly shown that 1) certain glycosaminoglycans (GAGs) which are present in the female genital tract will induce the capacitation/acrosome reaction (Lenz et al, $1982,1983 b$ ) and 2) the GAG, heparin, appears to be superior to chondroitin sulphate (Parrish et al, 1985) in terms of fertilization rates. The proportion of oocytes penetrated by sperm is greatest when fresh semen is incubated with heparin for at least $4 \mathrm{~h}$ (Parrish et al, 1988) and frozen-thawed semen for $15 \mathrm{~min}$ (Parrish et al, 1986) prior to mixing sperm with oocytes. The concentration of heparin varies according to the type of semen and between bulls (Leibfried-Rutledge et al, 1989). The mechanisms behind the induction of capacitation have been thoroughly described by First and Parrish (1987). In general, changes occur in the spermatozoa plasma membranes which allow uptake of $\mathrm{Ca}^{2+}$ activation of a C-AMP dependent protein kinase. In this context it is worthwhile emphasizing that glucose will inhibit the effect of heparin-induced capacitation (Parrish et al, 1985, 1989). Combined with a swim up technique which separates motile from immotile spermatozoa, treatment with $10 \mu \mathrm{g} / \mathrm{ml}$ heparin gives rise to repeatable and predictable fertilization rates of bovine oocytes matured in vivo, as well as in vitro (Parrish et al, 1986). Presently, this system seems to be the predominant treatment used to prepare sperm for fertilization in vitro. However, Fukui et al (1990) recently found that the optimal heparin dosage ranges from 25 to $100 \mu \mathrm{g} / \mathrm{ml}$.
The effect of heparin may be enhanced by caffeine (Niwa and Ohgoda, 1988). It is also noteworthy that the spermatozoa from different bulls give different frequencies for both fertilization and embryonic development in vitro (Brackett et al, 1982; Sirard and Lambert, 1985; Leibfried-Rutledge et al, 1987; Miller and Hunter, 1987; Ohgoda et al, 1988; and Eyestone and First, $1989 \mathrm{~b})$. The research of Ohgoda et al (1988) indicates that this effect is unrelated to the bull's in vivo fertilizing capability. However, heparin at a low concentration $(0.05 \mu \mathrm{g} / \mathrm{ml})$ seems to be optimal for evaluating in vivo fertility of different bulls (Marquant-Le Guienne et al, 1989).

It is therefore necessary to test each bull to ascertain that optimal heparin concentration and/or number of sperm are used for IVF (Leibfried-Rutledge et al, 1989). It is also important to take into consideration that each bull has its own contribution to in vitro fertilization and embryonic development (Hillary et al, 1990; Shi et al, 1990).

\section{Coculture of sperm and oocytes}

The fertilization medium used for coculture of sperm and oocytes consists of TALP placed in $50-\mu$ l droplets, and overlaid with sterile silicone or paraffin oil (Ball et al, 1983; Leibfried-Rutledge et al, 1987). In general, 10 oocytes are added to each 50 microliter droplet, which also contains $1 \times$ $10^{6}$ live spermatozoa per $\mathrm{ml}$. Coculture is conducted approximately $20-22 \mathrm{~h}$ at $39^{\circ} \mathrm{C}$ in an atmosphere of $5 \% \mathrm{CO}_{2}$ in air.

\section{Assessment of fertilization in vitro}

Assessment of fertilization is important since it has been established that oocytes 
matured both in vivo and in vitro may be pathenogenetically activated, therefore leading to invalid conclusions concerning actual fertilization rates (Xu et al, 1986b; King et al, 1988). This activation is apparently an age-dependent process (Ware et al, 1989). It is very important that one can distinguish between an activated oocyte and a fertilized egg; presence of part of the sperm tail (midpiece) and a maternal and paternal pronucleus indicate that fertilization has taken place. Abnormalities (polyspermy and others) are likely to occur (Xu et al, 1988b) due to deviating oocyte maturation and/or fertilization (Hyttel et al, $1989 \mathrm{a}$ and $1989 \mathrm{~b})$. In this study, fertilization and parthenogenetic activation were approximately $60 \%$ and $12 \%$, respectively.

\section{CULTURE OF FERTILIZED EGGS}

Until recently, successful culture of fertilized bovine oocytes was limited to the use of sheep oviducts (Lu et al, 1987; Fukui et al, 1989; Leibfried-Rutledge et al, 1989; Lu et al, 1989) or rabbit oviducts (Fukui and Ono, 1988; Fukui et al, 1989). However, methods of in vitro culture that utilize coculture with bovine oviduct epithelial cells (BOEC) (Fukui and Ono, 1988; Fukui et al, 1989; Eyestone and First, 1989a; Gordon and Lu, 1990; Madison et al, 1991), granulosa cells (Goto et al, 1988; Berg and Brem, 1989), trophoblastic vesicles (Heyman and Ménézo, 1987; Aoyagi et al, 1989 ) or culture in conditioned medium (Eyestone and First, 1989a) are very effective and have become the preferred method for the culture of embryos produced in vitro. The rate of development may be improved by adding estrous cow serum, rather than FCS, to the culture medium and omitting hormones (Fukui, 1989). Culture in domestic chicken eggs has also been carried out successfully, although the method is not commonly used (Blakewood et al, 1989). In vitro results, which are comparable with those in vivo, have been reported by Marquant-Le Guienne et al (1989) who added TGF $\beta$ at the beginning of blastocyst formation.

Studies by Gandolfi and Moor (1988) and Gandolfi et al (1989) indicate that at least two proteins from oviductal fluid (92 and $46 \mathrm{kDa}$ ) are involved in supporting embryonic development. Future studies will indicate whether these two proteins or other substances, such as growth factors, are secreted by the BOEC and are thus responsible for the positive effect of using coculture with oviduct cells. In our laboratory using BOEC the average rates of cleavage (6- to 16-cells on day 3 ) and development to the morula/blastocyst stage for the total oocytes exposed to sperm were $40 \%$ and $34 \%$, respectively.

The advantages of using the in vitro system are as follows: there is no need to maintain live animals in the laboratory vicinity; rates of recovery are higher than after agar embedding, transfer to the oviduct, and flushing 5-6 days later; there are more possibilities for detailed stublies of embryonic development; and fertilized oocytes or embryos may be used at various stages for other experimental procedures, such as cloning and gene transfer. The disadvantages are a possible decrease in embryonic development rate and probably reduced viability aftet transfer to the final recipient, particularly if the embryos are previously frozen or split by micromanipulation.

\section{FINAL COMMENTS}

The techniques of in vitro maturation and in vitro fertilization of cattle oocytes and culture of fertilized eggs and embryos have 
made tremendous progress during the last 5-10 years. It is now realistic to predict that readily available and inexpensive embryos can be produced from slaughterhouse ovaries and will be on the market for experimental and commercial purposes. The problems are, however, still many and must be solved before the efficiency of producing embryos or off-spring with in vitro techniques is greater than achieved with natural procedures.

It may be possible to improve the proportion of transferable embryos by ultrasonically guided transvaginal oocyte aspiration (Kruip et al, 1990). This technique may be performed two to three times during an estrous cycle in a cow for as long as 6 months (Pieterse et al, 1990; Greve, unpublished data, 1990). If this procedure yielded 5-10 oocytes per cycle, it would be possible with the current rates of fertilization and blastocyst formation to achieve 12 calves from the aspirations during a 3 week period.

\section{REFERENCES}

Aoyagi $Y$, Fukui $Y$, Iwazumi $Y$, Urakawa M, Minegishi $Y$, Ono $H$ (1989) Effects of culture system on development of in vitro-fertilized bovine ova into blastocysts. Theriogenology 31 , 168

Baker TG, Hunter RHF (1978) Interrelationships between the oocyte and somatic cells within the graafian follicle of mammals. Ann Biol Anim Biochim Biophys 18, 419-426

Ball GD, Leibfried ML, Lenz RW, Ax RL, Bavister BD, First NL (1982) Bovine fertilization in vitro: a temperature sensitive process. $\checkmark$ Anim Sci 336

Ball GD, Leibfried ML, Lenz RW, Ax RL, Bavister BD, First NL (1983) Factors affecting successful in vitro fertilization of bovine follicular oocytes. Biol Reprod 28, 717-725

Ball GD, Leibfried ML, Ax RL, First NL (1984) Maturation and fertilization of bovine oocytes in vitro. J Dairy Sci 67, 2775-2785
Bavister BD (1989) A consistently successful procedure for in vitro fertilization of golden hamster eggs. Gamete Res 23, 139-158

Berg U, Brem G (1989) In vitro production of bovine blastocysts by in vitro maturation and fertilization of oocytes and subsequent in vito culture. Zuchthyg 24, 134-139

Blakewood EG, Pool SH, Wiemer KE, Godke RA (1989) Culturing early-stage bovine morulae using domestic chicken eggs. Theriogenology 31, 176

Bondioli KR, Wright RW Jr (1983) In vitro fertilization of bovine oocytes by spermatozoa capacitated in vitro. J Anim Sci 57, 1001-1005

Boone WR, Shapiro SS (1990) Quality control in the in vitrofertilization laboratory. Theriogenology 33, 23-50

Brackett BG (1983) A review of bovine fertilization in vitro. Theriogenology 19, 1-15

Brackett BG (1985) In vitro oocyte maturation and fertilization. J Anim Sci 61, 14-24

Brackett BG, Bousquet D, Boice ML, Donawick WJ, Evans JF, Vessel MA (1982) Normal development following in vitro fertilization in the cow. Biol Reprod 27, 147-158

Callesen H, Greve T, Hyttel P (1986) Preovulatory endocrinology and oocyte maturation in superovulated cattle. Theriogenology 25, 7186

Critser ES, Leibfried-Rutledge ML, Eyestone WH, Northey DL, First NL (1986) Acquisition of developmental competence during maturation in vitro. Theriogenology 25, 150

Crozet N (1989) Nucleolar structure and RNA synthesis in mammalian oocytes. J Reprod Ferti' (suppl) 38, 9-16

Crozet N, Kanka J, Motlik J, Fulka J (1986) Nucleolar fine structure and RNA synthesis in bovine oocytes from antral follicles. Gamete Res 14, 65-73

Eyestone WH, First NL (1989a) Co-culture of early cattle embryos to the blastocyst stage with oviducal tissue or in conditioned medium. J Reprod Fertil 85, 715-720

Eyestone WH, First NL (1989b) Variation in bovine embryo development in vitro due to bulls. Theriogenology 31, 191

First NL, Parrish JJ (1987) In vitro fertilization of ruminants. J Reprod Fertil 34, 151-165 
Fukui $Y$ (1989) Effects of sera and steroid hormones on development of bovine oocytes matured and fertilized in vitro and cocultured with bovine oviduct epithelial cells. J Anim Sci 67, 1318-1323

Fukui $Y$, Ono $\mathrm{H}$ (1988) In vitrodevelopment to blastocyst of in vitro matured and fertilized bovine oocytes. Vet Res 122, 282

Fukui Y, Ono H (1989) Effects of sera, hormones and granulosa cells added to culture medium for in vitromaturation, fertilization, cleavage and development of bovine oocytes. J Reprod Fertil 86, 501-506

Fukui Y, Sakuma Y (1980) Maturation of bovine oocytes cultured in vitro: relation to ovarian activity, follicular size and the presence or absence of cumulus cells. Biol Reprod 22, 669-673

Fukui Y, Terawaki Y, Ono H (1982a) Effects of gonadotropins on in vitro maturaton of bovine follicular oocytes. Jap J Fertil Steril 27, 179-187

Fukui $Y$, Fukushima $M$, Terawaki $Y$, Ono $H$ (1982b) Effect of gonadotropins, steroids and culture media on bovine oocyte maturation in vitro. Theriogenology 18, 161-175

Fukui Y, Fukushima M, Ono H (1983) Fertilization in vitro of bovine oocytes after various sperm procedures. Theriogenology 20,651 660

Fukui $Y$, Imai K, Alfonso NF, Ono $H$ (1987) Follicle culture enhances fertilizability and cleavage of bovine oocytes matured in vitro. JAnim Sci 64, 935-941

Fukui T, Glew AM, Gandolfi F, Moor RM (1988) In vitro culture of sheep oocytes matured and fertilized in vitro. Theoriogenology 29, 883-891

Fukui Y, Urakawa M, Sasaki C, Chikamatso N, Ono $H(1989)$ Development to the late morula or blastocyst stage following in vitro maturation and fertilization of bovine oocytes. Anim Reprod Sci 18, 139-148

Fukui $Y$, Sonoyama $T$, Mochizuki $H$, Ono $H$ (1990) Effects of heparin dosage and sperm capacitation time on in vitro fertilization and cleavage of bovine oocytes matured in vitro. Theriogenology 34, 579-591

Fukusima M, Fukui Y (1985) Effects of gonadotropins and steroids on the subsequent ferti- lizability of extrafollicular bovine oocytes cultured in vitro. Anim Reprod Sci 9, 323-332

Gandolfi F, Moor RM (1988) Interactions between somatic and germinal cells during early development. 11th Int Congr Anim Reprod \& Al 5,170

Gandolfi F, Brevini TAL, Moor RM (1989) Effect of oviduct on embryonic development. $J R e$ prod Fertil suppl 38, 107-115

Gordon I, Lu KH (1990) Production of embryos in vitro and its impact on livestock production. Theriogenology $33,77-87$

Goto K, Kajihara Y, Kosaka S, Koba M, Makanishi $Y$, Ogawa $K$ (1988) Pregnancies after coculture of cumulus cells with bovine embryos derived from in vitro fertilization of in vitro matured follicular oocytes. J Reprod Fertil 83 , 753-758

Greve T, Bousquet D, King WA, Betteridge KJ (1984) In vitro fertilization and cleavage of in vivo matured bovine oocytes. Theriogenology 22, 151-165

Greve T, Xu KP, Callesen H, Hyttel P (1989a). Calves resulting from in vitro fertilization of oocytes. Zuchthyg (Berl) 24, 79-83

Greve T, Callesen H, Hyttel P (1989b) Follicular correlates with in vitro fertilization in cattle. $J$ Reprod Fertil suppl 8, 117-126

Grimes RW, Ireland JJ (1986) Relationship of macroscopic appearance of the surface of bovine ovarian follicles, concentrations of steroids in follicular fluid, and maturation of oocyles in vitro. Biol Reprod 35, 725-732

Hensleigh HC, Hunter AG (1985) In vitro maturation of bovine cumulus enclosed primary oocytes and their subsequent in vitro fertilization and cleavage. J Dairy Sci 68, 1456-1462

Heyman $Y$, Ménézo J (1987) Interaction of trophoblastic vesicles with bovine embryos developing in vitro. In: The Mammalian Preimplantation Embryo. Regulation of Growth and Differentiation in Vitro (BD Bavister, ed) Plenum Press 171-191

Hillary FL, Parish JJ, First NL (1990) Bull specific effect on fertilization and embryo development in vitro. Teriogenology 33, 249

Hyttel P, Callesen H, Greve T (1989a) A comparative ultrastructural study of in vivo versus in vitro fertilization of bovine oocytes. Anat Embryol 179, 435-442 
Hyttel P, Greve T, Callesen H (1989b) Ultrastructure of oocyte maturation and fertilization in superovulated cattle. In: Developments in Ultrastructure of Reproduction. Alan $R$ Liss Inc, 287-297

Hyttel P, Greve T, Callesen H (1989c) Ultrastructural aspects of oocyte maturation and fertilization in cattle. J Reprod Fertil suppl 38, 35-47

Katska L, Smorag Z (1985) The influence of culture temperature on in vitro maturation of bovine oocytes. Anim Reprod Sci 9, 205-212

King WA, Bousquet D, Greve T, Goff AK (1986) Meiosis in bovine oocytes matured in vitro and in vivo. Acta Vet Scand 27, 267-279

King WA, Xu KP, Sirard MA, Greve T, Leclerc P, Lambert RD, Jacques P (1988) Cytogenetic study of parthenogenetically activated bovine oocytes matured in vivo and in vitro. Gamete Res 20, 265-274

Kruip T AM, Pieterse MC, van Beneden T H, Vos P, Wurth YA, Taverne MAM (1990) Increased success rate of IVM and IVF in the bovine after sonographic guided transvaginal collections of the oocytes. Theriogenology 33, 269

Le Guienne B, Thibault C, Chupin D, Gérard M, Thibier $M$ (1988) Fécondation in vitro chez les mammifères domestiques. Elevage ot insémination 225, 13-22

Liebfried L, First NL (1979) Characterization of bovine follicular oocytes and their ability to mature in vitro. J Anim Sci 48, 76-86

Liebtried-Rutledge ML, Critser ES, First NL (1985) Fertilization potential of follicular oocytes classified by stage of cycle and size of follicle. Theriogenology 23, 753-759

Liebfried-Rutledge ML, Critser ES, Eyestone WH, Northey DL, First NL (1986a) Developmental potential of bovine oocytes matured in vitro or in vivo. Theriogenology 25, 164

Liebfried-Rutledge ML, Critser ES, First NL (1986b) Effects of fetal calf serum and bovine serum albumin on in vitro maturation and fertilization of bovine and hamster cumulusoocyte complexes. Biol Reprod 35, 850-857

Leibfried-Rutledge ML, Critser ES, Eyestone WH, Northey DL, First NL (1987) Development potential of bovine oocytes matured in vitro or in vivo. Biol Reprod 36, 376-383

Leibfried-Rutledge ML, Critser ES, Parrish JJ First NL (1989) In vitro maturation and fertili- zation of bovine oocytes. Theriogenology 31 , 61-74

Lenz RW, Ax RL, Grimek HJ, First NL (1982) Proteoglycan from bovine follicular fluid enhances an acrosome reaction in bovine spermatozoa. Theriogenology 106, 1092-1098

Lenz RW, Ball GD, Leibfried ML, Ax RL, First NL (1983a) In vitro maturation and fertilization of bovine oocytes are temperaturedependent processes. Biol Reprod 29, 173179

Lenz RW, Ball GD, Lohse JK, First NL, Ax RL (1983b) Chondroitin sulfate facilitates an acrosome reaction in bovine spermatozoa as evidenced by light microscopy, electron microscopy and in vitro fertilization. Biol Reprod 28, 683-690

Liehman P, Greve T, Xu KP (1986) Nuclear and cytoplasmic maturation of bovine oocytes cultured with dbc AMP, FSH and hCG. Acta Vet Scand 27, 566-574

Lu KH, Gordon I, Gallagher M, McGoyern H (1987) Pregnancy established in cattle by transfer of embryos derived from in vitro fertiization of oocytes matured in vitro. Vet $R \theta c$ 121, 259-260

Lu KH, Gordon I, Chen HB, Gallagher M, McGovern $H$ (1988) Birth of twins after transfer of cattle embryos produced by in vitro techniques. Vet Rec 122, 539-540

Lu KH, MacDonnel HF, Gordon I (1989) Birth of calves after in vitro maturation and fertilization of follicular oocytes. Theriogenology 31, 222

Lutterbach A, Koll RA, Brem G (1987) In vitro maturation of bovine oocytes in coculture with granulosa cells and their subsequent fertilization and development. Zuchthyg 22, 145-150

Madison V, Greve T, Avery B, Wamberg T (1991) The effect of endotoxin-contaminated medium on in vitro fertilization and development of bovine oocytes matured in vitro. $R \theta-$ prod Nutr Dev 31 (in press)

Marquant-Le Guienne B, Gérard M, Solari A, Thibault $C$ (1989) In vitro culture of bovine egg fertilized either in vivo or in vitro. Reprod Nutr Dev 29, 559-568

Marquant-Le Guienne B, Humblot P. Thibier M, Thibault C (1990) Evaluation of bull semen 
fertility by homologous in vitro fertilization tests. Reprod Nutr Dev 30, 259-266

Miller DJ, Hunter AG (1987) Individual variation for in vitro fertilization success in dairy bulls. J Dairy Sci 70, 2150-2153

Moor RM (1978) Role of steroids in the maturation of ovine oocytes. Ann Biol Anim Biochim Biophys 18, 477-482

Moor RM, Crosby IM (1985) Temperatureinduced abnormalities in sheep oocytes during maturation. $J$ Reprod Fertil 75, 467-473

Moor RM, Seamark RF (1986) Cell signaling, permeability, and microvasculatory changes during antral follicle development in mammals. J Dairy Sci69, 927-943

Moor RM, Polge C, Willadsen SM (1980) Effect of follicular steroids on the maturation and fertilization of mammalian oocytes. $J E m$ bryol Exp Morphol 56, 319-335

Moor RM, Crosby IM, Osborn JC (1983) Growth and maturation of mammalian oocytes. $\mathrm{n}$ : In vitro Fertilitzation and Embryo Transfer 1 , 39-59

Niwa K, Ohgoda O (1988) Synergistic effect of caffeine and heparin on in vitro fertilization of cattle oocytes matured in culture. Theriogenology $30,733-741$

Ohgoda O, Niwa K, Yuhara M, Takahashi S, Kanoya K (1988) Variations in penetration rates in vitro of bovine follicular oocytes do not reflect conception rates after artificial insemination using frozen semen from different bulls. Theriogenology 29, 1375-1381

Osborn JC, Moor RM (1982) Cell interactions and actin synthesis in mammalian oocytes. $J$ Exp Zool 220, 125-129

Osborn JC, Moor RM (1983) The role of steroid signals in the maturation of mammalian oocytes. J Steroid Biochem 19, 133-137

Parrish JJ, Susko-Parrish JL, First NL (1985) Effect of heparin and chondroitin sulphate on the acrosome reaction and fertility of bovine sperm in vitro. Theriogenology 24, 537-549

Parrish JJ, Susko-Parrish JL, Leibfried-Rutledge ML, Critser ES, Eyestone WH, First NL (1986) Bovine in vitro fertilization with frozenthawed semen. Theriogenology 25, 591-600

Parrish JJ, Susko-Parrish J, Winner MA, First NL (1988) Capacitation of bovine sperm by heparin. Biol Reprod 38, 1171-1180
Parrish JJ, Susko-Parrish JL, First NL (1989) Capacitation of bovine sperm by heparin: inhibitory effect of glucose and role of intracellular $\mathrm{pH}$. Biol Reprod 41, 683-699

Pavlok A, Torner H, Motlik J, Fulka J, Kauffold P, Duschinski U (1988) Fertilization of bovine oocytes in vitro: effect of different sources of gametes on fertilization rate and frequency of fertilization anomalies. Anim Reprod Sci 16, 207-213

Pavlok A, Motlik J, Kanka J, Fulka J (1989) In vito techniques of bovine oocyte maturation, fertilization and embryo culture resulting in the birth of a calf. Reprod Nutr Develop 29, 611-616

Pieterse MC, Taverne MAM, Kruip T AM, Willemse AH (1990) The usefulness of ultrasonography in comparison with rectal palpation for the detection of bovine corpora lutea. Theriogenology 33, 297

Pollard JW, Xu KP, Rorie R, King WA, Betteridge KJ (1989) Influence of various oviductal epithelial cell culture systems on the development of early cleavage stage bovine embryos in vitro. Theriogenology 31, 239

Sanbuissho A, Threlfall WR (1989) The effect of estrous cow serum on the in vitro maturation and fertilization of the bovine follicular o0cyte. Theriogenology 30, 693-699

Schiewe MC, Shmidt PM, Wildt DE, Rall WF (1990) Quality control measures in an embryo research program. Theriogenology 33, 9-22

Shi DS, Lu KH, Gordon I (1990) Effects of bulls on fertilization of bovine oocytes and their subsequent development in vitro. Theriogenology 33,324

Shioya $Y$, Kuwayama $M$, Fukushima $M$, Iwasaki $S$, Hanada $A(1988)$ In vitro fertilization and cleavage capability of bovine follicular oocytes classified by cumulus cells and matured in vitro. Theriogenology 30, 489-496

Sirard MA (1989) Practical aspects of in-vitro fertilization in cattle. J Reprod Fertil suppl 38, 127-134

Sirard MA (1990) Temporary inhibition of meiosis resumption in vitro by adenylate cyclase stimulation in immature bovine oocytes. Theriogenology 33, 757-788

Sirard MA, Lambert RD (1985) In vitro fertilization of bovine follicular oocytes obtained by laparoscopy. Biol Reprod 33, 487-494 
Sirard MA, Lambert RD (1986) Birth of calves after in vitro fertilization using laparoscopy and rabbit oviduct incubation of zygotes. Vet Rec $119,167-169$

Sirard MA, First NL (1988) In vitro inhibition of oocyte nuclear maturation in the bovine. Biol Reprod 39, 229-234

Sirard MA, Parrish JJ, Ware CB, LeibfriedRutledge ML, First NL (1988) The culture of bovine oocytes to obtain developmentally competent embryos. Biol Reprod 39, 546552

Staigmiller RB (1988) In vitro methods for production of viable oocytes. J Anim Sci suppl 2, $66,54-64$

Staigmiller AB, Moor RM (1984) Effect of follicle cells on the maturation and developmental competence of ovine oocytes matured outside the follicle. Gamete Res 9, 221-229

Stubbings RB, Betteridge KJ, Basrur PK (1988) Investigations of culture requirements for bovine oocyte maturation in vitro. Theriogenology 29,313

Süss U, Wüthrich K, Stranzinger G (1988) Chromosome configurations and time sequence of the first meiotic division in bovine oocytes matured in vitro. Biol Reprod 38, 871-880

Tan SJ, Lu KH (1990) Effects of different oestrous stages of ovaries and sizes of follicles on generation of bovine embryos in vitro. Theriogenology 33,335

Thibault C, Gérard M, Ménézo Y (1976) Nuclear and cytoplasmic aspects of mammalian oocyte maturation in vitro in relation to follicle size and fertilization. In: Progress in Reproductive Biology (Hubinont PD, ed) vol 1, Karger, Basel, 233-240

Thibault C, Szöllösi D, Gérard M (1987) Mammalian oocyte maturation. Reprod Nutr Dev 27, 865-896

Utsumi K, Katoh H, Iritani A (1988) Developmental ability of bovine follicular oocytes matured in culture and fertilized in vitro. Theriogenology 29, 320

Ware CB, Barnes FL, Maiki-Laurila M, First NL (1989) Age dependence of bovine oocyte activation. Gamete Res 22, 265-275

Wright Jr RW, Bondioli KR (1981) Aspects of in vitro fertilization and embryo culture in domestic animals. J Anim Sci 53, 702-729

Xu KP, Greve T (1988b) A detailed analysis of early events during in vitro fertilization of bovine follicular oocytes. J Reprod Fertil 82, 127-134

Xu KP, Greve T, Smith S, Hyttel P (1986a) Chronological changes of bovine follicular oocyte maturation in vitro. Acta Vet Scand 27, 505-519

Xu KP, Greve T, Smith S, Liehman P, Callesen $\mathrm{H}$, Hyttel $\mathrm{P}$ (1986b) Parthenogenetic activation of cattle oocyte matured in vitro and cultured in rabbit oviduct. Theriogenology 25 , 218

Xu KP, Greve T, Callesen H, Hyttel P (1987) Pregnancy resulting from cattle oocyte matured and fertilized in vitro. J Reprod Fert 81 , 501-504

Xu KP, Høier R, Greve T (1988a) Dynamic changes of estradiol and progesterone concentrations during in vitro oocyte maturation in cattle. Theriogenology 30, 245-255

Yang YB, Lu KH (1990) The influence of bovine oocyte type on in vitro fertilization and subsequent development in vitro. Theriogenology 33, 355

Yang NS, Lu KH, Gordon I (1990) In vitro fertilization (IVF) and culture (IVC) of bovine oocytes from stored ovaries. Theriogenology 33, 352

Younis Al, Brackett BG, Fayer-Hosken RA (1989) Influence of serum and hormones on bovine oocyte maturation and fertilization in vitro. Gamete Res 23, 189-201 